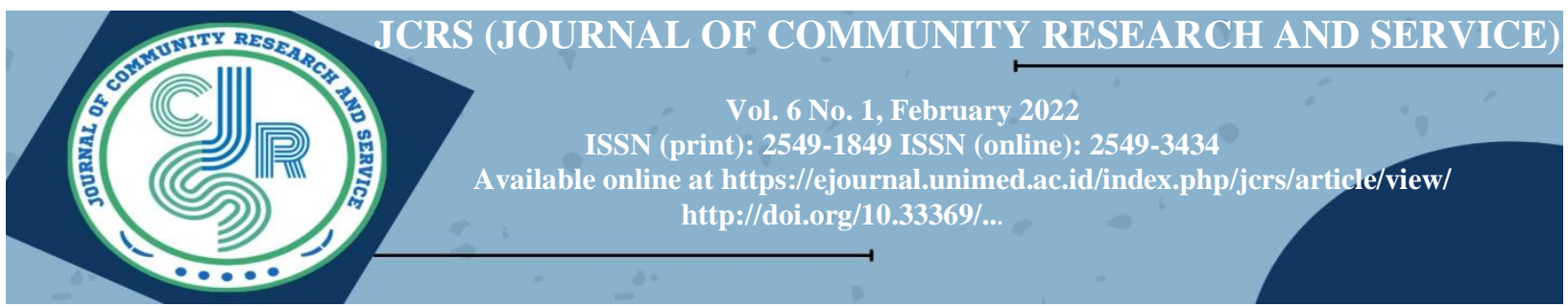

\title{
Development of Project-Based ICT and Media E-Modules for Learning During the Covid-19 Pandemic
}

\author{
Nur Basuki \\ Faculty of Engineering, Universitas Negeri Medan, INDONESIA \\ nurbasuki@unimed.ac.id
}

\begin{abstract}
Media courses and learning are courses that describe the basic concepts of knowledge, theoretical understanding, and practice of effective and efficient learning media in the teaching and learning process. The emodule was developed using the Dick and Carey (2005) model which has 10 steps, namely: 1) the stage of the need and determining general goals, 2) conducting a learning analysis, 3) identifying behaviors and early learners, 4) writing specific learning objectives, 5) compiling learning outcome tools, 6) developing learning strategies, 7) selecting and developing learning materials, 8) implementing and implementing formative evaluations, 10 carrying out evaluations, and carrying out evaluations. Modules that have passed the development stage that needs to be evaluated. The purpose of this development research is to produce e-modules for media and information and communication technology courses for learning in the Department of Mechanical Engineering Education, Faculty of Engineering, State University of Medan. The results of the development, based on the results, that the validity of the e-module material obtained a score of 92 which was in the very good category, the validity of the learning design was 93.91, the media aspect was 90.00. Student assessment 85.77. In conclusion, the E-module for media and typewriting courses for learning is suitable for use in classroom or online learning during the COVID-19 pandemic. The implication of this research result is used as input for lecturers. Fixing yourself is related to the problems that have been carried out and student achievement that has been achieved by paying attention to appropriate learning methods to improve student learning achievement.
\end{abstract}

Keywords: e-modules, Covid-19 Pandemic Learning, media and typos for learning

Article history: Received: 01-12-2021; Revised: 10-12-2021; Accepted: 01-02-2022; Available online: 26-02-2022

How to cite this article: Basuki, N., (2022) Development of Project-Based ICT and Media E-Modules for Learning During the Covid-19 Pandemic. Journal of Community Research and Service,6(1), xxx-xxx.

https://doi.org/10.14710/ijred.x.X.Xxx-xxx

\section{Introduction}

Covid-19 began to become the center of the world's attention on January 20, Covid-19 has claimed thousands of victims and is still a frightening specter. In Indonesia, Covid-19 only received attention when President Jokowi announced that there were Indonesian citizens who were positive for the coronavirus. This announcement was delivered on (2/3/2020) with 2 positive people. Even though the announcement regarding positive Indonesian citizens did not prevent residents from continuing their activities and considered it just an ordinary virus. Entered in 3 months the victims fell and the more positive, initially 2 people became hundreds of positive victims so that the government policy to LockDown was issued.

This government policy is none other than for the common good even though there are many considerations in society. This government policy has an impact on the teaching and learning process, both elementary, junior high, high school, and even tertiary institutions. Entering the second week of month 3 all universities in Indonesia will be suspended for 2 weeks or 14 days. This stop initially made the students happy because they got 2 weeks off and could be used to return to their hometowns or take a walk. But gradually, terminating lectures is not a sign that the teaching and learning process is also being eliminated but it is still being carried out online or online. 
Medan State University has taken preventive measures to protect all students, lecturers, and staff from transmission or infection of the coronavirus by carrying out the lecture process through an online learning platform. This is based on the UNIMED Chancellor's Decree dated March 16, 2020, that UNIMED Chancellor Circular Number: 000809 / UN33 / SE / 2020, regarding online learning and working from home for residents of Medan State University anticipating the spread of the coronavirus at UNIMED [1].

The digital era is increasingly developing today, the use of technology in this era is also growing rapidly which can be used as a learning solution at home during the COVID-19 pandemic. One of the uses of technology is in the field of education through digital applications for the development of electronic-based materials/books and so on. It is undeniable that many lecturers and students are dependent on smartphones or computers so that it is easy to access information anywhere and anytime without any time and space limitations.

Learning is a system. The quality of the process and learning outcomes can be influenced by the quality of the components in learning. The learning components consist of [2]: a) students, b) the learning process, c) graduates with the expected competencies, d) educators, e) curriculum, and f) learning materials. The components of the learning system that also influence the learning process and outcomes are instructional materials. Teaching materials are a set of materials that contain learning materials or content designed to achieve learning objectives [3].

There are various types of teaching materials, one of which is modules. Teaching modules are a form of print-based teaching materials designed for independent learning by students, therefore the module is equipped with instructions for self-study [4]. Modules have a more complete structure when compared to textbooks and textbooks. However, the existence of modules is still limited, especially for media and typewriting courses for learning in the Mechanical Engineering Education Department. The printed textbooks used so far have many limitations. First, picture messages in textbooks are still printed in black and white. One of the characteristics of textbooks in media and typewriting courses for learning is that they contain more pictures than textbooks in general. When examined from the aspect of message design, the use of black and white images is not justified. However, if it is printed in color, it will be burdensome for students in terms of printing costs. Second, the results of preliminary observations indicate that students have not used textbooks optimally. Students read more textbooks when they are going to get a presentation assignment or do other assignments. This is related to the lack of textbook interactivity, especially practice questions. So far, the weakness of practice questions in textbooks, especially the multiple-choice ones, does not immediately provide feedback. New feedback can be given if face-to-face lectures have been conducted. The immediate feedback can help learners know their learning progress [5]. Feedback can reinforce what has been learned and can also correct misunderstandings. During the current COVID-19 pandemic, learning activities must be carried out at home with the aim of breaking the chain of transmission of COVID-19, with this exposure currently an e-module is needed as a learning medium that can be accessed online whenever and wherever students are.

In addition to the COVID-19 pandemic problem, the main problem is the limitation of textbooks for media and typewriting courses for learning, problems are also found in the habits of students reading. Based on the results of a survey of 47 students of the Department of Mechanical Engineering Education in February 2020, the following data were obtained.

Table 1. Old Smartphone Usage Among Students.

\begin{tabular}{ccccc}
\hline Less than & $1-3$ hour & $3-7$ hour & $\begin{array}{c}\text { More than } 7 \\
\text { hour }\end{array}$ & Other \\
\hline $4(8,5 \%)$ & $9(19,1 \%)$ & $13(27,7 \%)$ & $21(44,7 \%)$ & $0(0 \%)$ \\
\hline
\end{tabular}

More than 6 hours per day students actively use smartphones. This indicates that students are more interested in reading digital reading. Furthermore, as many as $63.8 \%$ of students read digital reading materials more often, through social media or the web. The survey results indicate that technological developments have changed student habits from reading printed teaching materials to digital reading. Remembering digital reading can be accessed easily and practically. Thus, it is necessary to develop digital teaching materials to keep up with current developments in information technology.

Media and typing courses for learning are courses that describe the basic concepts of knowledge, theoretical understanding, and practice of making learning media that are effective and efficient in the teaching and learning process. The subject matter of this course includes: (1) The meaning of the role of 
media in communication and learning (2) Definition, function, and use of learning media, (3) The basis of learning media (4) Classification of learning media (5) Selection procedures and principles of use Media (6) Original and Non-Original Object Media, (7) Two-dimensional media: board media (8) Graphic media (9) Listening and viewing media (10) Production of presentation media (visual, audio, video), and (11) Research on learning media. At the end of this course, students are able to plan and design a production of instructional media that is developed based on the characteristics of subjects in schools that can be used as a tool in teaching practice field experiences.

Based on the observation that students are more motivated to do assignments that have real benefits and are more contextual. However, the textbooks that have been used so far are still very few project tasks. In the 21 st century, cooperative and collaborative project completion skills are indispensable in the world of work. There are several deficiencies in the current media and typewriting textbooks, problems in the learning process, and the development of information and communication technology (ICT), it is deemed necessary to develop a project-based electronic module (e-module). E-module is an effort to anticipate technological developments from printed teaching materials to digital teaching materials. Given current developments, students often read via smartphones, so e-modules are a necessity in today's digital era. This e-module has advantages over the print module. First, the e-module can be accessed online either via a laptop or smartphone. Considering that the characteristics of media and typing courses for learning are theory and practice of planning and designing a production of instructional media that is developed based on the characteristics of subjects in schools that can be used as a tool in teaching practice field experiences, it will be more practical if students are facilitated e -module. Second, the e-module facilitates students to learn independently. Students can access the e-module anytime and anywhere by using a smartphone.

The images presented in the module are all colored with high resolution making it easier for students to interpret the content of the material. Third, the e-module provides interactive questions and quizzes so that it can measure the level of mastery of the material at the end of the learning activity. This is an effort to overcome the weaknesses of the print module, where the answer key can be seen by students. Fourth, the e-module contains several authentic projects. The project element in the e-module requires students to work together and collaborate to complete predetermined project topics. Some of the skills that can be developed through project completion are: 1) group learning skills, 2) life skills, 3) cognitive skills (making decisions, thinking critically, solving problems), 4) self-management skills (setting goals and organizing tasks), 5) develop a positive attitude, 6) self-direction and 7) increase self-confidence [6]. From the description above, it can be concluded that the project-based e-module for Media and ICT Courses for Learning in the Department of Mechanical Engineering Education, FT, is effectively used. The purpose of this research is to produce an electronic module (e-module) for media and ICT courses in learning at the Department of Mechanical Engineering Education, Faculty of Engineering, State University of Medan. Based on the explanation above, it is important to develop project-based e-modules for Media and Typing Courses for Learning in the Department of Mechanical Engineering Education, FT Unimed, which are presented online during learning during the current COVID-19 pandemic.

\section{Method}

This type of research is development research. The development research is research-oriented to develop and validate products used in education [7]. The development model used is the Dick and Carey (2005) model which consists of 10 stages as shown in Figure 1 [8]. 


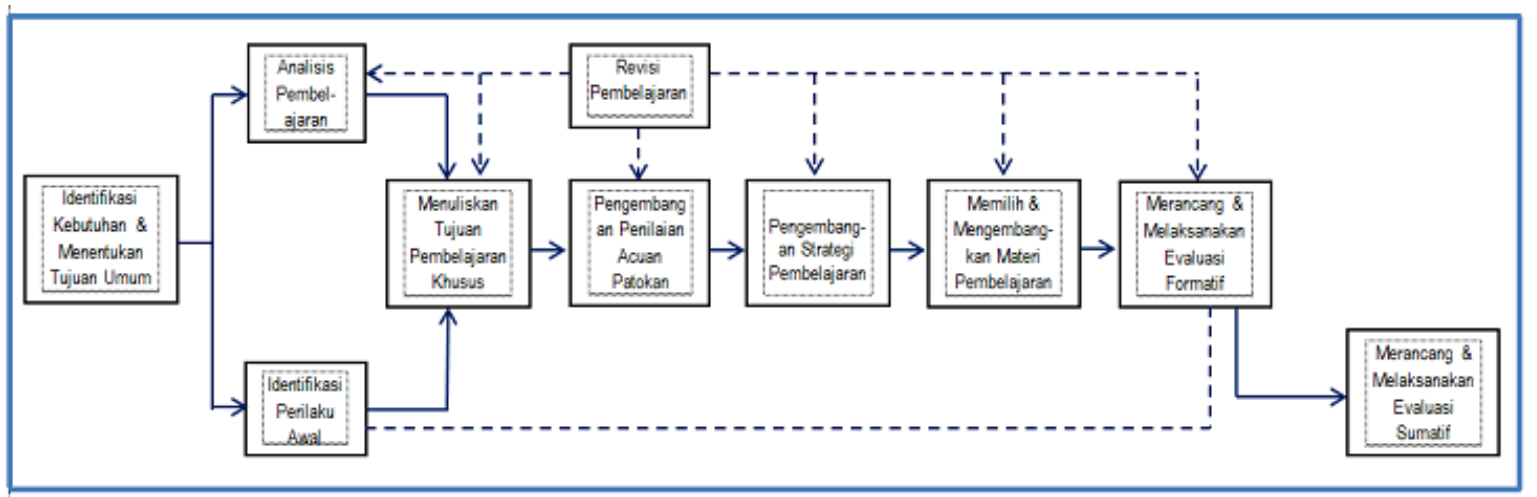

Fig. 1. Dick and Carey’s development model.

As a result of development, the e-module must go through a series of trials to determine its validity level. The level of validity of textbooks can be determined through the analysis of expert reviews, lecturers who teach subjects, individual tests, and small group tests. The following is a product trial design.

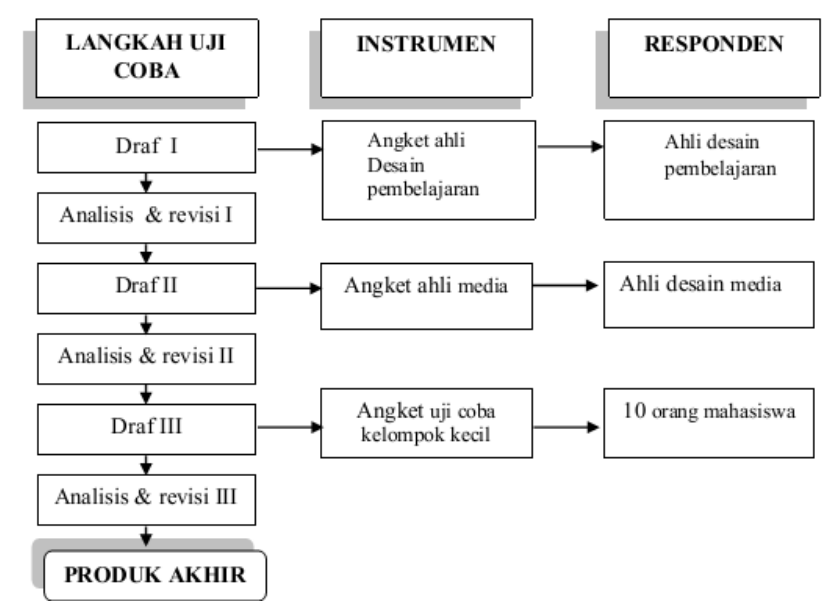

Fig. 2. Product Development Draft Trial Design.

Data were collected using the method of observation and questionnaires. The observation method was used when conducting a preliminary study. The questionnaire was used to obtain data from experts, lecturer assessments, individual trials, and small group trials. Efforts to ensure the validity of the questionnaire were carried out by making grid tables and writing instruments. The data that has been collected using a questionnaire method then analyzed using qualitative descriptive analysis and quantitative descriptive analysis. Qualitative descriptive analysis is used to analyze (media or e-learning modules) information about the form of responses and views. This method is used to analyze the comments and suggestions of experts and respondents during individual trials and small group trials. The results of the analysis are used to revise the development of product design.

\section{Findings and Discussion}

The e-module development was successfully developed using the Dick and Carey (2005) model as follows:

\subsection{Identification of Needs and Determining General Goals}

At this stage, a problem was found that students had difficulty building and implementing media and typographic knowledge or theory for learning during the learning period during the Covid-19 pandemic. So that this problem encourages to development of a teaching e-module that is oriented towards project 
completion which is a means of implementing the theory of media and typography subjects in learning. After problems are found, the next step is to formulate competencies. The competency in question is general competence or known as general instructional objectives. The competencies are: (1) Students can understand media development and its characteristics, (2) students can understand storyboards, (3) students are familiar with Adobe Macromedia Flash, video editing, animation, a sound, narrative, and the language of the macro media program (4) students can apply the techniques in the practice of making learning media

Table 2. Results of Student Characteristics Analysis.

\begin{tabular}{|c|c|c|}
\hline No & Characteristics & Information \\
\hline 1 & General Characteristics & $\begin{array}{l}\text { The average age of students is } 19-20 \text { years, the average } \\
\text { students from middle and lower economies, the average } \\
\text { student is three in the village, all students are male. }\end{array}$ \\
\hline 2 & Competence & $\begin{array}{l}\text { Students are able to operate computers and software, } \\
\text { students are familiar with software, students understand the } \\
\text { development of learning media, students understand the } \\
\text { techniques of operating Adobe Macromedia Flas } 8 \text { software. }\end{array}$ \\
\hline 3 & Motivation to learn & $\begin{array}{l}\text { Students' intrinsic motivation to develop themselves is quite } \\
\text { good, Intrinsic motivation tends to increase when lectures } \\
\text { are more practical than theoretical exposure, Organizing } \\
\text { students in efficient study groups grows } \\
\text { external motivation. }\end{array}$ \\
\hline 4 & Learning style & $\begin{array}{l}\text { In general, the learning style of concrete sequential students } \\
\text { is that students like direct learning experiences (hands on } \\
\text { experience) organized systematically, for example by using } \\
\text { programmed learning activities and exercises, and } \\
\text { information comprehension styles. In general, students have } \\
\text { a visual learning style. The speed at which students } \\
\text { understand messages and information can be effective if } \\
\text { delivered } \\
\text { through pictures, practicum, and demonstrations. }\end{array}$ \\
\hline
\end{tabular}

The results of the competency analysis and the results of the analysis of student characteristics are used as a reference for collecting material for making e-modules. The material is collected through books, research articles, sources on the internet, and the experiences of researchers teaching media and ICT courses in learning.

Evaluation of the validity of e-modules through three aspects, namely the validity of the material, the validity of the learning design, and the validity of the learning media. To find out the validity, two experts were used, one person assessed the material aspects and learning design aspects and the other assessed the learning media aspects. Based on the expert's judgment, the validity of the e-module media and ICT material in learning is in the very good category with a percentage of $92 \%$. The validity of the learning design aspects is in the good category with a percentage of $93.91 \%$. The validity of the learning media aspects is in the very good category with a percentage of $90 \%$. Visually it can be presented in Figure 5.2 below. 


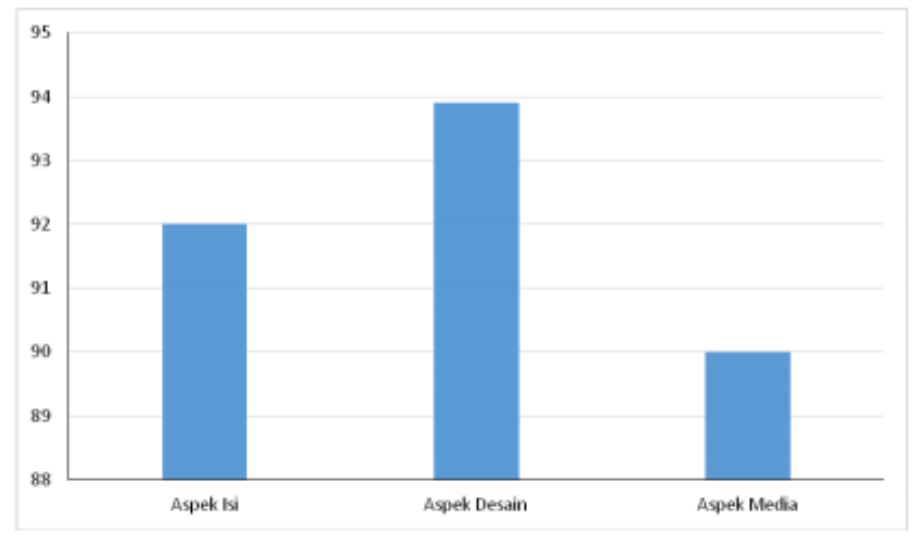

Fig. 3. Acquisition of the Validity Level of Material Aspects, Design, and Media Aspects in the Assessment of e-Module Media and ICT in Learning.

In addition to the validity of these three aspects, e-module media and ICT in learning were also assessed by students who gave an assessment that the e-module was in the good category with a percentage of $85.7 \%$. The e-module has been successfully developed using the Dick and Carey model. This model has provided systematic steps so that the development process is more optimal and minimizes errors that occur. E-modules that have been successfully developed have also been validated by material experts as well as design experts and learning media experts.

Based on the material expert's assessment, the e-module content is in a very good category with a percentage of $92 \%$. Obtaining this cannot be separated from several aspects. First, the knowledge presented in the e-module is suitable for learning to students. The preparation of the contents of the emodule refers to books that are in accordance with the demands of competency in media and ICT courses in learning. Book selection is based on the characteristics of the competency achievement indicators in each module. The sources referred to are also up-to-date so that they are relevant to reference. Content writing also uses references from articles in journals. The contents of the e-module are also interrelated and form a flow that is easy to understand. Order of presentation of contents from easy to difficult, from known to unknown, and from knowledge to application. The contents of the e-module are presented with a learning activity system that consists of five modules in total.

Based on the material expert's assessment, the e-module content is in the very good category with a percentage gain of $92 \%$. Obtaining this cannot be separated from several aspects. First, studied from the aspect of the formulation of learning objectives, it has been developed based on the competencies or performance that students must have. The formulation of learning objectives is then followed by the breadth of material coverage, so that material reviews are able to support the achievement of learning objectives. In addition to the suitability of material coverage, the assessment method has also been based on the formulation of operational indicators or verbs of learning objectives. Thus, the assessment method for each module will be different, according to the level of ability being measured. Second, examined from the aspect of message delivery methods or strategies, e-modules are considered capable of triggering student interest and involvement in learning. Delivery of material based on the characteristics and complexity of knowledge. Third, examined from the aspect of the project assignment, it is considered capable of encouraging challenging learning and collaborative efforts as well as part of the assessment.

\section{Conclusion}

Producing a good and interesting electronic module for learning is not easy. The process begins with the planning, manufacturing, and product validation stages through an expert judgment process and student responses. The planning stage is the initial stage of determining the module content and learning media to be used. The manufacturing stage is the stage of designing the module which is then presented in electronic form in the form of a flipbook. While the product validation test stage consists of testing the experts (experts) to provide assessments and input both in terms of the content of the module material and the learning media used. Based on the results of the expert, the content of the module is good for use and the learning media in the form of an electronic module in the form of a computer-based flipbook and 
network are good enough and suitable for use because this electronic module has received positive ratings in its very easy operation. Music and animation elements are considered to be able to increase motivation, interest, and learning activities of students.

In addition, student responses are needed as a reference for whether the electronic module presented in the form of a flipbook is interesting to use. This stage is the initial stage of development before the flipbook electronic module is actually used in learning. The results of the validation test regarding student responses to the flipbook form electronic module were good. In this study, students as a sample of users considered flipbooks interesting to use in learning because they provided an alternative to new learning media.

\section{References}

[1] Surat Keputusan Rektor UNIMED tanggal 16 Maret 2020.

[2] Suparman MA. Desain instruksional modern. Jakarta: Erlangga; 2018.

[3] Sungkono. Pengembangan Bahan Ajar. Yogyakarta: FIP UN; 2017.

[4] Asyhar R. Kreatif Mengembangkan Media Pembelajaran. Jakarta: Gaung Persada (GP) Press Jakarta; 2017.

[5] Gee JM. Learning by design: Good video games as learning machines. E-Learning. 2005; 2(1):5 16.

[6] Buck Institute for Education. Project based learning for the 21st century. 2018.

[7] Borg, Gall. Education Research. New York: Allyn and Bacon; 2003.

[8] Dick W, Carey L, Carey JO. The systematic design of instruction. Boston: Pearson; 2005. 